US support for malaria research

Sir - I applaud the attention you have given to the Multilateral Initiative on Malaria (MIM) ${ }^{1}$, but I wish to correct statements in your most recent News report $\mathrm{t}^{2}$ and leading article $\mathrm{e}^{3}$ about the position of the US National Institutes of Health (NIH) on the initiative.

Although we have been prepared to consider "a common, centrally managed fund for malaria research", at least on a small scale, the position we clearly espoused at the recent meeting in The Hague was different: a coordinated review of proposals for collaborative research involving African scientists, with funding by individual agencies according to their own priorities.

It is also inaccurate to say that we were "springing... radical proposals" on our intended partners; the several options for interactions among funding agencies had been discussed previously in Dakar and were circulated among the agencies before the meeting in The Hague.

Furthermore, you inappropriately cast us as Jamesian upstarts, when in fact the United States supports more than half of the world's research on malaria, including substantial work in Africa ${ }^{4}$.

Missing from your coverage of the recent meeting, however, was the central feature of MIM to which many agencies had subscribed at a previous meeting in April 1996: the intention of developing stronger and more interactive science in Africa through efforts on malaria, in collaboration with Northern partners. I hope that, in broadening the scope of its efforts to advocacy and fund-raising, the MIM does not lose sight of that important objective.

Despite the evident resistance in The
Hague to mechanisms for multilateral support, we at the NIH are encouraged by the dedication of our partners to malaria research, eager to pursue the tasks assigned to us (proposals for a basic science agenda for malaria and for improved electronic communications in Africa), committed to further increases in fiscal support for malaria research and enthusiastic about both the original and the expanded goals of the MIM.

\section{Harold Varmus}

(Director)

National Institutes of Health, Bethesda, Maryland 20892, USA

\footnotetext{
1. Butler, D. Nature 386, 535-540 (1997).

2. Nature 388, 211 (1997).

3. Butler, D. Nature 388, 219 (1997).

4. Malaria Research, An Audit of International Activity, PRISM Report No. 7 (The Wellcome Trust, September 1996).
}

\section{EMBO fellows go home}

Sir - The European Molecular Biology Organisation (EMBO) is one of the organizations that award postdoctoral fellowships in molecular biology. The fellowships are funded by the 21 member states of the European Molecular Biology Conference (EMBC).

Recipients have to move to a different (usually European) country for the period of the fellowship.

It is obviously important to know if these fellowships prove successful in a science career. Another question is whether the fellows remain in the country they visited or return home.

EMBO has therefore carried out a survey in which EMBO fellows from 1984-85 (approximately 200 in all) were traced by a Medline search of recent publications or followed by direct contact with the receiving institute for the fellowship or with their original home institute. The use of Medline as a primary screen for the fellows ensured that there was not a bias in favour of those who had been successful and therefore were more likely to respond to questionnaires. Given that more than 10 years had elapsed since the award of the fellowships, it was expected that the data obtained would be of relevance to their final career path. Eighty-seven per cent of the fellows were traced. Of these, 88 per cent were visibly involved in research (that is, had publications cited in Medline in the past two years) and 7 per cent were in industry.
Of particular relevance to EMBO and to the EMBC is the fact that 73 per cent of the fellows had returned and were working in their home country. This figure is particularly notable, because 29 per cent of those who received fellowships in those years carried out their research in laboratories outside Europe.

The quality of the positions of the fellows was also analysed. Eighty per cent had permanent jobs, of whom 36 per cent were in a professorial post or its equivalent in their home country. One final aspect of the survey is that it showed that the careers of the female fellows were indistinguishable from, and as successful as, those of the men.

The results of this survey reinforce EMBO's long-held belief that its fellowships contribute significantly to the scientific life of the country from which the fellow comes, and that those selected as EMBO fellows are of a very high calibre, judging by their subsequent career paths. A more detailed report providing the statistics summarized here is available on the EMBO website: http://www.EMBO.org

Frank Gannon

Jennifer Norman

Mare Kriis

Anne Walter

EMBO, Meyerhofstr. 1,

D-69117 Heidelberg, Germany

Lars Breimer

Clinical Research Division,

Sanofi Winthrop,

1 Onslow Street,

Guildford, Surrey, UK

\section{Nightmare antibiotics}

Sir - Harder and colleagues recently reported a new peptide antibiotic produced in human skin (Nature 387, 861; 1997) — a fascinating piece of detective work. Their closing statement, however, is giving me nightmares.

They suggest that this and other endogenous human peptide antibiotics "might be ideal therapeutic agents, avoiding the problems of acquired resistance".

Of course, another antibiotic to turn to when all else fails would, no doubt, temporarily relieve the problems of increasing resistance to the existing antibiotic armoury.

But imagine the consequences if this antibiotic were overused as others have been, and microorganisms developed resistance to it.

This is the stuff of science fiction horror - Satan bugs which have acquired resistance to an endogenous defence mechanism that has been protecting our ancestors for millions of years.

Perhaps this is one agent that should be kept where it belongs, in what is literally the last line of defence our skin.

\section{Chris F. Inglehearn}

Department of Molecular Genetics, Institute of Ophthalmology, University College London, Bath Street,

London ECIV 9EL, UK

e-mail:cinglehe@hgmp.mrc.ac.uk 